\title{
The Impact of Share Pricing on Firm Performance: Empirical Evidence from Pakistan
}

\author{
MUHAMMAD ILYAS \\ Lecturer and PhD Scholar, Institute of Business Studies and Leadership \\ Abdul Wali Khan University, Mardan \\ milyas_85@awkum.edu.pk \\ DR.SHAHID JAN \\ Associate Professor, Institute of Business Studies and Leadership \\ Abdul Wali Khan University, Mardan \\ shahidjan@awkum.edu.pk \\ MUHMMAD NISAR KHAN \\ Lecturer, Bacha Khan University, Charsadda \\ nisarmgt@bkuc.edu.pk
}

\begin{abstract}
Researchers examined the impact of share pricing on firms performance in Pakistan. Selected 98 firms from five different sectors listed on Karachi Stock exchange. Selected sample on the bases of availability of complete data of sample firms during period of this study (2006-2011). Data used are secondary in nature and source of data is balance sheet analysis of listed firms. Used Net profit margin as depended variable while earnings per share used as independent variable and return on assets overhe ${ }^{l}$ ads and earnings before interest and tax used as control variables. For analysis used Panel data techniques as fixed and random effect models. On the basis of Hauseman effect test select fixed effect model for analysis and concluded that the impact of earnings per share, earnings before interest tax and overheads are significant on net profit margin. However, impact of return on assets on net profit margin is insignificant.
\end{abstract}

Keywords: Share Price, Karachi Stock Exchange, Net Profit Margin, Earnings Per Share

\section{Introduction}

In the area of business and especially of finance the financial system as a whole plays an important role in any economy developmental process. In this area the capital market plays a vital role because it is an essential part of financial system. Moreover, stock exchange is a performance measure parameter of any economy. As an integral part of the whole financial system the stock exchange role is to mobilize savings, allocate resources in an efficient way. In case of Pakistan the stock market are still not developed though it start working in 1947 after independence, but it still provide its basic function of liquidity in efficient manner. Karachi stock exchange helps the economy and all sectors of economy by providing services to firms, investors and all other stockholders.

\footnotetext{
${ }^{1}$ Now Karachi Stock Exchange is Pakistan Stock Exchange. 
As we know the primary objective of any firm manager to enhance the value of firms for their shareholders and it is also clear from literature and empirical evidences that the shares price is play an important role in performance of market. Share price consider as a signal and as well a proxy for liquidity function of stock market. The investment in sense of securities as financial investment and it leads to the expansion of business investment in sense of economic investment. This investment from investors side in form of financial sense leads firm into economic sense of investment improve the status of firm by gaining long term funds, build positive image of firm in community, help in financial performance of firms and also provide an incentive clue for employees. In this research work the main concentration is focus to find out how share price effect the performance of firms and the shareholder face the risk. As any manager manages the internal appears of firms to maximize the value of firm, here therefore focus share pricing to affect either firm performance or not. From the literature revealed that researchers investigate the share pricing effect on firm performance in firms which offer initial public offerings. However, the share pricing also effect the performance of these firms which made already initial public offerings and now their share normally traded on stock exchange. Therefore, in this study researchers reveal to investigate the share pricing impact on firm performance of already offered initial public offerings.

\section{Review of Literature}

Gyimah and Akotey (2011) examined the effect of share pricing on performance of listed firms on Ghana stock exchange. Net profit margin used as dependent variable and EPS as independent variable and ROA, ROE, ROI and overheads used as control variables. Five companies used as sample of study and data is panel in nature. For the purpose of analysis used the random effect model and from results concluded that the relation of EPS and performance of firms is significant and positive. However, ROI and overheads are significantly but negatively related with performance of firms. ROA and ROE are insignificantly explain this relationship, concluded that the share price attract investors for investment. Ritter (1991) worked on USA public firms and concluded from the results that after going public in first 3 to 5 years their returns are negative and significant. Moreover, Jain and kini (1994) investigate the operating performance of quoted companies during time period of 1976-1988. It was early time going public firms in USA and from results conclude that in their post issue performance are declined. However, revealed that investors expect that earnings growth of these public firms will continue and investors value such firms.

Kim, Moonchul and Ray (2004) examined the Thai initial public offerings and concluded that their operating performance declined, also find that firms depend on banking mode of finance face high performance decline in post listing period and growing firms performed well. Kutsuna, Hideo and Cowling (2002) studies JASDAQ companies and concluded that sales, ordinary profit and net growth in profits decrease after listing. Pagano, Panetta and Zingales (1998) analyzed Italian IPOs determinants and compare ex-post characteristics of these IPOs and firms of private. After IPO their profitability declined and increases after first years to third years. Cai and Wei (1997) examined the operating performance of initial public offering in Japanese firms in first five years and its concluded that these firms underperformed significantly. 


\section{Hypothesis}

In the light of above discussion the following hypothesis is generated for testing on the basis of their theoretical background.

\section{Research Methodology}

Ho: There is no impact of share pricing on firm performance.

In this research work researchers examined the impact of share pricing on performance of listed firms on Karachi stock exchange. 98 listed firms from five different sectors are selected. Data is secondary in nature and source of data is balance sheet analysis for non-financial firms. Time period is six years from 2006 to 2011.

As the data is panel in nature therefore, used the panel data techniques for analysis. The general model is:

$\mathrm{Y}_{\mathrm{it}}=\alpha+\beta \mathrm{X}_{\mathrm{it}}+\mathrm{u}_{\mathrm{it}}$

These techniques are common effect, random effect and fixed effect models. In case of common effect model there is a constant intercept for all cross sectional over the time periods, and in the case of fixed effect model the intercept for all cross sectional are fixed over time not constant.

$\mathrm{Y}_{\mathrm{it}}=\alpha+\beta_{1} \mathrm{X}_{1 \mathrm{it}}+\beta_{2} \mathrm{X}_{2 \mathrm{it}}+\beta_{3} \mathrm{X}_{3 \mathrm{it}}+\ldots \ldots \ldots+\beta_{\mathrm{k}} \mathrm{X}_{\mathrm{kit}}+\mathrm{u}_{\mathrm{it}}$

In the situation of random effect model the situation of intercept of all cross sectional are random over time.

$\mathrm{Y}_{\mathrm{it}}=\alpha+\beta_{1} \mathrm{X}_{1 \mathrm{it}}+\beta_{2} \mathrm{X}_{2 \mathrm{it}}+\beta_{3} \mathrm{X}_{3 \mathrm{it}}+\ldots \ldots \ldots+\beta_{\mathrm{k}} \mathrm{X}_{\mathrm{kit}}+\left(\mathrm{v}+\mathrm{u}_{\mathrm{it}}\right)$

For the best model selection for panel data estimation techniques use the Hausman effect to select fixed or random effect model.

\subsection{Variables and Its Measurements}

\subsubsection{Dependent variable}

Net Profit Margin (NPM): It is calculated by net profit divided by sales.

\subsubsection{Independent Variable}

Earnings per Share (EPS): It means how much earning generated by a firm on per share basis. Calculated by using formula of total earning of firm divided by total number of outstanding shares.

\subsubsection{Control Variables}

Return on Assets (ROA): Calculated by net income by total assets.

Operating Profit Margin: It is calculated by EBIT divided by sales.

Overheads: It is calculated by overheads divided by total assets.

\subsection{Research Model}

For this study the research or statistical model is design on the basis of regression model.

$\mathrm{NPMt}=\alpha+\beta_{1} \mathrm{EPSt}+\beta_{2} \mathrm{ROAt}+\beta_{3} \mathrm{OVt}+\beta_{4} \mathrm{EBITt}+\varepsilon$

NPMt is a net profit margin for firm at time $t$.

EPSt is earning per share for firm at time $t$.

ROAt is return on assets for firm at time $t$.

$\mathrm{OVt}$ is overheads for a firm at time $t$.

EBITt is operating profit margin for a firm at time $t$. 


\section{Results and Discussion}

\subsection{Fixed Effect Estimation Results}

Dependent Variable: NPM

Method: Panel Least Squares

Sample: 20062011

Periods included: 6

Cross-sections included: 588

Total panel (unbalanced) observations: 3524

\begin{tabular}{|crrrr|}
\hline Variable & Coefficient & Std. Error & t-Statistic & Prob. \\
\hline \hline C & -0.014414 & 0.003372 & -4.274484 & 0.0000 \\
EPS & 0.000984 & 0.000503 & 1.957133 & 0.0504 \\
EBIT & 1.347836 & 0.010292 & 130.9540 & 0.0000 \\
ROA & 0.007144 & 0.084719 & 0.084330 & 0.9328 \\
OH & -0.242235 & 0.053568 & -4.521987 & 0.0000 \\
\hline \hline \multicolumn{5}{|c|}{ Effects Specification } \\
\hline \hline
\end{tabular}

R-squared $\quad 0.842894$

Adjusted R-squared $\quad 0.842402$

Panel data model of fixed effect estimation is applicable for this data. Net Profit Margin (NPM) used as dependent variable in this study and from the results concluded that earning per share (EPS) is significantly and positively related with net profit margin. Means when earning per share of firm increase the performance of firm will leads to high level and this support the view that share pricing has positive relation with firm performance. Earnings before interest tax (EBIT) and overheads $(\mathrm{OH})$ are also have significant relationship with net profit margin, coefficient of overhead is negative, and it means inverse relation. Results of this study have similarities in conclusion with Gyimah and Akotey (2011) that overheads and earning per share are significantly related with net profit margin. Moreover, earnings before interest and tax has positively and significantly related with net profit margin. Return on assets (ROA) is insignificantly and positively related with net profit margin. This insignificant association of return on assets and net profit margin support the results of Gyimah and Akotey (2011). 
Correlated Random Effects - Hausman Test

Equation: Untitled

Test cross-section random effects

\begin{tabular}{|lrrr|}
\hline Test Summary & Chi-Sq. Statistic & Chi-Sq. d.f. & Prob. \\
\hline \hline Cross-section random & 34.151738 & 6 & 0.0000 \\
\hline
\end{tabular}

To decide either fixed effect estimation or random effect estimation model is best for panel data analysis applied the Hauseman effect test. Result of Hauseman test provide the information that the fixed effect estimation is suitable for this study and random effect estimations test is not appropriate because the value of $\rho$ value is less than 1 percent.

\section{Conclusion}

As in this study the researchers examined the impact of share pricing on the performance of firms listed on Karachi stock exchange, from the panel data analysis concluded that earnings per share, earnings before interest and tax and overheads have significant relationship with net profit margin. However, relationship of return on assets is insignificant with net profit margin. Therefore, concluded that the share prices effect the performance of firms listed on stock exchange.

\section{References}

Cai, J. \& Wei, K. C. J. (1997). The investment and operating performance of Japanese IPOs. Pacific-Basin Finance Journal, 5, 389-417.

Gyimah S.F \& Akotey. J. O (2011). Effects of share pricing on firms' performance in Ghana. Journal of economics and sustainable development, 2(4), 140-154.

Jain, B. A. \& Kini, O. (1994). The post-issue operating performance of IPO firms. Journal offinance, 49, 1699-1726.

Kim, Moonchul \& Ray R. R. (1999). Valuing IPO's. Journal of financial economics, 53, $409-437$.

Kutsuna, K., Hideo, O. \& Cowling, M. (2002). Ownership structure, Pre and Post IPOs and the operating performance of JASDAQ companies. Pacific-basin finance journal, 10(2), 163-181.

Pagano, M., Panetta, F. \& Zing Ales, L. (1998). Why do companies go public? An empirical analysis. The journal of finance, 53, 27-64.

Philip, R. (1998). Stock exchange shares and foreign exchange. Business Review Weekly, 30-33.

Ritter, J.R. (1991). The long run performance of initial public offerings. Journal of finance 46, 3-28. 